\title{
The ministerial power to set up a public inquiry: issues of transparency and accountability
}

\author{
EMMA IRETON ${ }^{1}$
}

Nottingham Law School

\begin{abstract}
The Independent Panel Inquiry into Child Sexual Abuse was left in crisis following intense pressure from survivors and their families, the public and media. Two senior legal figures, Baroness Butler-Sloss and Fiona Woolf, both resigned from the position of chair to the inquiry following concerns over their links with the establishment. Questions were raised over the independence of a process convened by the Home Secretary, to investigate apparent failures on the part of institutions, which would include scrutinising the actions of a former Home Secretary in handling allegations of child sexual abuse in the past. Demands for an inquiry with greater statutory powers, including the power to compel the giving of evidence on oath, ultimately resulted in the Independent Panel being disbanded and a new public inquiry, the Independent Inquiry into Child Sexual Abuse, being convened. Against the background of this and other inquiries, this article examines the serious questions raised about the powers of a minister to set up a public inquiry, the lack of open and transparent decision-making processes and the extent to which those ministerial decisions are open to public scrutiny and accountability.
\end{abstract}

\section{Introduction}

ne of the key functions of a public inquiry convened by a minister into a matter of public concern is to hold those in authority to account. It is therefore essential that a public inquiry is set up in such a way as to command public confidence and trust in the independence and integrity of the resultant inquiry and its findings. The establishment of the Independent Panel Inquiry into Child Sexual Abuse in $2014^{2}$ prompted an eight-month period of intense pressure and lobbying from the survivors and their families, the public and the media, who were unhappy with the way in which it had been convened. It resulted in the resignation of two chairs to the inquiry, the original panel being dissolved and a new public inquiry, the Independent Inquiry into Child Sexual Abuse (IICSA) ${ }^{3}$ being convened on a statutory basis. ${ }^{4}$

1 I am very grateful to Robert Lee and Jonathan Doak for much helpful insight into the development of this article.

2 An independent inquiry panel of experts in the law of child protection to consider whether public bodies and other non-state institutions have taken seriously their duty of care to protect children from sexual abuse: HC Deb 7 July 2014, vol 584, col 25.

$3<$ www.iicsa.org.uk/>

4 HC Deb 7 July 2014, vol 584, col 25. Hearings are due to commence in 2016. 
The Seven Principles of Public Life, ${ }^{5}$ devised by the Committee on Standards in Public Life, ${ }^{6}$ set out the basis of the ethical standards expected of public office-holders. They include the requirement for openness:

Holders of public office should act and take decisions in an open and transparent manner. Information should not be withheld from the public unless there are clear and lawful reasons for so doing.

And accountability:

Holders of public office are accountable to the public for their decisions and actions and must submit themselves to the scrutiny necessary to ensure this. ${ }^{7}$

Whilst not legally binding, these principles have come to inform public life and other codes of conduct, such as the Ministerial Code, ${ }^{8}$ which sets out the standards of conduct expected of ministers, and also to inform legislation. ${ }^{9}$ In this article I argue that the lack of open and transparent decision-making processes when a public inquiry is convened and the absence, in the public domain, of clear published criteria and reasoning behind those decisions, restricts the scope for public scrutiny and accountability. This in turn can damage public confidence in the ensuing public inquiry and its findings, by giving rise to concerns over the motives behind the decisions made and a lack of independence of the inquiry process from government and the executive.

Ministerial decisions taken when convening a public inquiry may be challenged by judicial review, but there are a number of practical limitations to this as a safeguard. Ministers are accountable to Parliament and the electorate and, as the IICSA itself illustrates, public pressure can influence ministerial decisions. However, there is no formal process by which representations may be made to the minister, nor any requirement for public consultation. The extent to which the public and interested parties have influenced such decisions has varied widely between inquiries.

By way of background, with particular reference to the IICSA, and also to other key public inquiries such as the Mid Staffordshire NHS Foundation Public Inquiry (hereinafter Mid Staffordshire Inquiry), Litvinenko and Chilcot Inquiries, ${ }^{10}$ this article firstly examines the considerable discretion afforded to the minister over whether or not an inquiry is convened, what powers an inquiry is given, the appointment of its chair and the setting of its terms of reference, which all have a fundamental impact on the nature of the inquiry and public perception of its independence and integrity. Secondly, it analyses the extent to which the exercise of that discretion is transparent and open to public scrutiny and accountability and the scope for victims, survivors and their families, and the wider public, to influence or challenge the decisions reached.

The 2014 House of Lords Select Committee on the Inquiries Act 2005 (hereinafter the HL Select Committee) provided the first parliamentary post-legislative scrutiny of the Inquiries Act 2005 and considered the law and practice relating to inquiries into matters of public concern, in particular those convened under the Inquiries Act 2005 (hereinafter

5 Committee on Standards in Public Life, 'The Seven Principles of Public Life' (May 1995). Also known as the Nolan Principles.

6 A public body that advises the UK government on ethical standards across public life in the UK.

7 Seven Principles (n 5) principles 5 and 4 respectively

8 The most recent version of which is the Cabinet Office, Ministerial Code, October 2015.

9 Such as the Freedom of Information Act 2000

10 Inquiry to examine the Commissioning, Supervisory and Regulatory Organisations in Relation to their Monitoring Role at Mid Staffordshire NHS Foundation Trust between January 2005 and March 2009; Inquiry to Investigate the Death of Alexander Litvinenko on 23 November 2006; Inquiry into the UK's involvement in the Conflict in Iraq. 
the 2005 Act). It took evidence from inquiry chairs and secretaries, lawyers and academics, inquiry witnesses, interest groups and others. This article draws on that evidence, the report produced (hereinafter 2014 Select Committee Report), ${ }^{11}$ and the government's written response (hereinafter Government Response), ${ }^{12}$ together with parliamentary debates, government publications, media reports and wider literature.

\section{Convening a public inquiry}

\section{ROLE}

Before considering the significance of the ministerial decisions taken while setting up public inquiries, it is helpful to first consider the role of public inquiries. Public inquiries may serve a number of different purposes: establishing the facts; determining accountability; learning lessons and making recommendations to prevent recurrence; restoring public confidence; catharsis; developing public policy and discharging investigative obligations under Articles 2 and $3^{13}$ of the European Convention on Human Rights (ECHR). ${ }^{14}$ They may also vary greatly in terms of the nature of their subject. Some cover events which suggest a breakdown in the rule of law, such as the Scott Inquiry, ${ }^{15}$ some involve a single death, such as the Victoria Climbie Inquiry, and others many deaths, as with the Shipman Inquiry. ${ }^{16}$ But what they all share is that they are inquiries into significant matters of public concern. ${ }^{17}$

A call for a public inquiry will frequently occur immediately following an event causing national concern. However, there may be a long delay, such as in the case of the IICSA, where calls for a public inquiry into wide-scale child abuse came years after the events, triggered by press reports on Jimmy Savile's behaviour, following his death in $2012 .{ }^{18}$ By the time a minister is faced with the decision of whether or not to convene a public inquiry, a momentum of public pressure may have built up from the media, the families of victims, victim support groups, non-governmental organisations (NGOs) and from the lobbying of Parliament by individuals and pressure groups. The minister may be under considerable pressure to act quickly. Many groups will express frustration at the apparent failures of the system and feel that, without a public inquiry, their voice will not be heard. ${ }^{19}$

11 HL Select Committee, The Inquiries Act 2005: Post-legislative Scrutiny (HL 2013-2014 143).

12 Ministry of Justice, Government Response to the Report of the House of Lords Select Committee on the Inquiries Act 2005 (Cm 8093 2014)

13 The rights to life and to not be tortured or subjected to torture or inhuman or degrading treatment or punishment.

14 List from Jason Beer et al, Public Inquiries (OUP 2011) paras 1.02-10

15 Inquiry into the Export of Defence Equipment and Dual-Use Goods to Iraq and Related Prosecutions.

16 Cabinet Secretary Advice Note on the Establishment of a Judicial Inquiry into Phone Hacking (19 March 2010) <www.gov.uk/government/uploads/system/uploads/attachment_data/file/60808/cabinet-secretaryadvice-judicial.pdf $>$.

17 On the role and functions of public inquiries, see also Mark Elliott and Robert Thomas, Public Law 2nd edn (OUP 2014) ch 17, para 2.2.

18 'Jimmy Savile Accused of Sexual Abuse' BBC News (1 October 2012) <www.bbc.co.uk/news/entertainmentarts-19776872>.

19 For example, see 'Bishop Calls for Buncefield Inquiry' Evening Standard (London, 11 January 2006) <www.standard.co.uk/newsheadlines/bishop-calls-for-buncefield-inquiry-7084716.html> and David Conn, 'Theresa May to Heed Campaigners' Call for Inquiry into Battle of Orgreave' The Guardian (London, 15 December 2015) <www.theguardian.com/politics/2015/dec/15/theresa-may-to-heed-campaigners-call-forinquiry-into-battle-of-orgreave $>$. 


\section{MINISTERIAL POWERS}

The decisions whether or not to convene an inquiry and, if so, its nature, are for the minister whose department is most relevant to the matter of public concern (as discussed in greater detail below). There is no process by which those demanding a public inquiry can make an application and the court cannot mandate a minister to call a public inquiry. Whilst Parliament does not itself have power to set up a public inquiry, it can exert political pressure on a minister to do so and the public may apply pressure on Parliament by lobbying both Houses, through letters, presentations, briefings and meetings and through the media. In the case of the IICSA, the announcement of a public inquiry came relatively soon after the call. However, in many cases, such as that of the Mid Staffordshire Inquiry, there may be a protracted period of campaigning before an inquiry is convened. ${ }^{20}$ In many cases, a call for an inquiry will be unsuccessful. ${ }^{21}$

The minister must also decide the extent to which any inquiry will be held in public. Not all inquiries into matters of public concern are public inquiries; inquiries may be held entirely in public, in private, or a combination of the two. (The Chilcot Inquiry is an example of a public inquiry that held a number of its hearings in private.) There is no automatic entitlement to a public inquiry as opposed to a private inquiry and, again, the decision as to whether the advantages of a closed inquiry outweigh those of an open inquiry is predominantly a matter for the minister. ${ }^{22}$ It seems right in principle that an inquiry into matters of public concern should itself be heard in public unless there is a strong public-interest argument for the inquiry, or some part of it, to be heard in private, ${ }^{23}$ for example, to protect matters of national importance or security. The 2005 Act includes a presumption that inquiries into matters of public concern will be held in public. However, as is argued below, ministers on occasions appear to be choosing to sidestep the use of this legislation, which has given rise to concerns that some such decisions may have been motivated by a wish to conceal or suppress some aspects of the truth from the public. There has been much debate over ministerial decisions to hold all or part of an inquiry in private, with many such decisions being the subject of judicial review proceedings, ${ }^{24}$ as well as public and media scrutiny.

A further decision for the minister is the basis upon which a public inquiry is to be convened. As considered in more detail below, inquiries may be statutory or non-statutory in nature. Most statutory inquiries are now held under the 2005 Act, s 1 of which provides that a minister 'may' cause an inquiry to be held under the Act. The power to convene a non-statutory public inquiry falls under the general ministerial prerogative. Again, ministerial discretion is extremely broad. There is no formula or criteria in the 2005 Act for convening a statutory inquiry beyond those stated in $\mathrm{s} 1$ :

20 See Julie Bailey oral evidence taken before the HL Select Committee (23 October 2013) Q173: 'Select Committee on the Inquiries Act 2002: Written and Corrected Oral Evidence' <www.parliament.uk/ documents/lords-committees/Inquiries-Act-2005/IA_Written_Oral_evidencevol.pdf>.

21 Such as the call for a public inquiry into the death of four soldiers at Deepcut Barracks and the death in custody of teenager Joseph Scholes

22 See Scott Baker JR (Persey) v Secretary of State for Environment, Food and Rural Affairs [2002] EWHC 371 (Admin), [2003] QB 794, para 69.

23 See Report of the Royal Commission on Tribunals of Inquiry (Cmnd 3121 1966) para 40 (Salmon Report).

24 See R $v$ Secretary of State for Health, ex parte Crampton (CA, 9 July 1993) (the Allitt Inquiry); R $v$ Secretary of State for Health, ex parte Wagstaff; R $v$ Secretary of State for Health ex parte Associated Newspapers Ltd [2001] 1 WLR 292 (the Shipman Inquiry); R (Persey) v Secretary of State for Environment, Food and Rural Affairs [2002] EWHC 371 (Admin) (the Foot and Mouth Inquiry). 
where it appears to him that-

(a) particular events have caused, or are capable of causing, public concern, or

(b) there is public concern that particular events may have occurred.

For a non-statutory inquiry, there are no criteria at all.

Precisely which minister is responsible for an inquiry is an administrative or political decision, rather than a legal one. An area of concern frequently raised is that the minister exercising the discretion, and making the decision about whether or not to set up a public inquiry, is often the minister for the department that is, or may find itself, under scrutiny. ${ }^{25}$ Equally, the actions of the government itself may be under scrutiny. ${ }^{26}$ This can generate significant public concern over the clear conflict of interest that arises and the lack of independence of an inquiry from government and ministerial departments.

Whilst setting up an inquiry should not be a political decision, political considerations frequently influence the decision. Calls for both the Marchioness and Mid Staffordshire Inquiries were initially refused by the then government, but promised by the opposition, which then convened the public inquiries on coming to power. ${ }^{27}$ The request for the Litvinenko Inquiry was initially refused because of concerns about damaging UK relations with Russia. ${ }^{28}$ It is an often-quoted belief ${ }^{29}$ that a minister will concede a public inquiry to appease immediate pressure from the public and media and kick the issues into the long grass', hoping that public interest and political criticism will have faded by the time the inquiry report is produced. 30

\section{TRANSPARENCY}

Concern over the motives behind a decision is exacerbated by the lack of transparency. As Eversheds ${ }^{31}$ noted in written evidence before the HL Select Committee, 'there is no transparency in the decision-making process conducted by Ministers/Government when deciding to set up, or not set up, an inquiry and the public is often not fully appraised of the reasons behind a particular decision being made'. ${ }^{32}$

Despite the fact that the 2005 Public Administration Select Committee report, Government by Inquiry, recommended that ministers should justify their decision whether or not to hold an inquiry based on a published set of criteria (and proposing some criteria that might form a basis for this), ${ }^{33}$ the later 2014 Select Committee Report rejected

25 For example, the Mid Staffordshire Inquiry.

26 For example, the Bloody Sunday and Chilcot Inquiries.

27 See, for example, Julie Bryant on the effect of the change of government on the call for the Mid Staffordshire Inquiry, oral evidence taken before the HL Select Committee (23 October 2013) Q162.

28 The Home Secretary admitting 'international relations' were a factor in the government's decision not to hold a public inquiry. See Terri Judd, 'Alexander Litvinenko death: Theresa May admits "international relations" affected Ruling' The Independent (London, 19 July 2013) <www.independent.co.uk/news/uk/politics/ alexander-litvinenko-death-theresa-may-admits-international-relations-affected-ruling-8720405.html > .

29 See, for example, Steve Richards, 'The Real Purpose of Public Inquiries' The Independent (London, 16 June 2010) and Simon Jenkins, 'Politicians Who Demand Inquiries Should be Taken Out and Shot' The Guardian (London, 25 June 2013).

30 The 2014 Select Committee Report noted that it had received no evidence of this for statutory inquiries though it did receive evidence from Liberty to the effect that this was the purpose of the Detainee Inquiry. See HL Select Committee (n 11) para 98.

31 An international law firm and solicitors to the Bloody Sunday, Shipman, Rosemary Nelson and Mid Staffordshire Inquiries, and who acted for the Metropolitan Police Authority in the Leveson Inquiry.

32 Eversheds' written evidence to the HL Select Committee (n 20) para 13.

33 Public Administration Select Committee, Government by Inquiry (HC 2004-2005, 51-I) para 184. 
similar suggestions made by witnesses before it. ${ }^{34}$ It warned 'there is a danger fixed criteria might fetter discretion and so limit the circumstances when an inquiry may be set up' and concluded that 'there neither can nor should be fixed criteria regulating the setting up of inquiries'. ${ }^{35}$ It also concluded that:

$\ldots$ it is right that the power to establish a public inquiry should be held by a minister of the relevant department. The fact that ministers are accountable to Parliament, and that Parliament can always call for an inquiry to be set up, allows sufficient Parliamentary involvement in the process.

Whilst recognising the need to avoid the introduction of over-prescriptive criteria, it is argued that the introduction of broad criteria or guidance, as well as engaging more openly with those campaigning for a public inquiry, and the wider public, at an early stage would go a long way towards addressing concerns and managing expectations.

In addition to the absence of published criteria by which the decision is reached, currently, there is not even a requirement for a minister to give reasons when refusing a public inquiry. Ministerial statements to Parliament are often, but not always, given. (Reasons that have been given include the thoroughness of earlier investigations, ${ }^{36}$ cost, time and money, and international relations. ${ }^{37} \mathrm{~A}$ minister may also be concerned about the possibility of setting a precedent, and thereby increasing calls for a public inquiry, as well as timing issues, for example, proximity to an election, which would raise questions over motivation.) ${ }^{38}$

Concluding that calls for a public inquiry are frequent and numerous and it would be impractical to record and respond to every call, ${ }^{39}$ rather than suggesting criteria for when reasons should be given, the Select Committee recommended that ministers retain a general discretion as to when to give reasons for their decisions, but added that reasons not to hold an inquiry should always be given to Parliament where there has been a 'failure in regulation' and following a request by a coroner to convert an inquest into an inquiry. 40 The government accepted there should be 'some explanation' of a decision not to convene a statutory inquiry, only in the circumstances identified and for domestic bodies, and following a request to convert an inquest, ${ }^{41}$ but there was no suggestion of legislative change.

Whilst this may go some way towards improving accountability to Parliament in these circumstances, it is argued that it does not go far enough to address wider concerns over the lack of transparency of the decision-making process and the effect on public confidence in the public inquiry process. There are frequent calls for clearer criteria and reasoning from those campaigning for public inquiries. ${ }^{42}$ The absence of any published criteria or guidance as to when an inquiry may or may not be convened, and the fact that there will be occasions when no reasons are given for refusing a public inquiry, exacerbates concerns about the motivation behind those decisions.

34 See, for example, Robert Francis QC, written evidence to the HL Select Committee (n 20) para 14.

35 HL Select Committee (n 11) para 51.

36 For example, the death of Daniel Morgan; the death of four soldiers at Deepcut Barracks; and Mid Staffordshire (decision later reversed).

37 The death of Alexander Litvinenko.

38 Cabinet Secretary Advice Note (n 16).

39 HL Select Committee (n 11) para 110.

40 Ibid paras 111-12.

41 Ministry of Justice (n 12) paras 33-36.

42 See, for example, Christopher Jefferies and Julie Bryant, oral evidence taken before the HL Select Committee (23 October 2013) (n 20) Q162 and 179. 


\section{LIMITED SCOPE FOR CHALLENGE}

In reaching a decision, the minister is exercising a public law function and the decision may therefore be challenged by way of judicial review. ${ }^{43}$ There have been many judicial review challenges to decisions refusing to convene a public inquiry, on the basis that the decision was unreasonable, bearing in mind the nature of the issue or the level of concern, or that the minister had taken into account irrelevant considerations in deciding to hold an inquiry, ${ }^{44}$ some of which have been successful. ${ }^{45}$ In such circumstances, the role of the court is one of review, not appeal. It cannot order a minister to convene an inquiry, but can require the minister to remake the decision, ${ }^{46}$ which may ultimately result in an inquiry being convened.

Such proceedings, however, have their limitations. In order to bring an application for judicial review, leave of the court is required, which will not be granted unless the court considers that the applicant has a 'sufficient interest' in the matter to which the application relates. ${ }^{47}$ Few ordinary members of the public with 'sufficient interest' are familiar with, or have access to the resources to bring, judicial review proceedings. Further, there is concern that recent controversial changes to judicial review introduced by the Criminal Justice and Courts Act 2015, including the tightening of the criteria for granting judicial review and changes to the rules on the legal costs of interveners in judicial review proceedings, will make it harder for individuals, the families of victims, survivor support groups, NGOs and pressure groups to challenge ministerial and governmental decisions, thus weakening judicial review as an important safeguard.

Judicial review is not, however, the only way in which the public may challenge a decision to refuse a public inquiry. Under the doctrine of ministerial responsibility, ministers are answerable to Parliament for their actions and the actions of their departments. As we have seen in the case of inquiries such as the IICSA, Mid Staffordshire and Chilcot Inquiries, public pressure from individuals and pressure groups via the media, social media and the lobbying of MPs, has a significant, albeit informal and non-legal role to play. 48 However, this form of informal public and political accountability has also given rise to concerns over inconsistency. It is dependent on wellmobilised groups building a sufficient momentum of publicity and wider public support to be able to influence ministers and Parliament. Numerous extraneous factors will come into play and this route, as a form of accountability, can by no means be assured.

43 A decision to refuse a public inquiry can be judicially reviewed irrespective of whether or not reasons are given.

44 See Cabinet Secretary advice note (n 16).

45 For example, Shipman (n 24); Baha Mousa, R (on the Application of Al-Skeini and Others) $v$ Secretary of State for Defence [2007] 3 All ER 685; and Litvinenko, R (on the Application of Litvinenko) v Secretary of State for the Home Department [2014] EWHC 194 (Admin).

46 See Jason Varuhas, 'Ministerial Refusals to Initiate Public Inquiries: Review or Appeal' (2014) 73(2) Cambridge Law Journal 238, criticising the court's approach in $R$ (Litvinenko) (n 45) as approaching the case as though it was hearing an appeal rather than exercising a supervisory function.

47 See Senior Courts Act 1981, s 31(3). The Act does not define 'sufficient interest', but leaves the decision to the court, which will consider, inter alia, the merits of the challenge, and whether or not personal rights or interests are involved: IRC v National Federation of the Self Employed and Small Businesses [1982] AC 617. Where judicial review is sought by survivor support groups, NGOs and pressure groups, the court may take into account the reputation of the body; whether a significant number of members are affected by a decision; and whether it is reasonable for the group or organisation to claim on behalf of its members: see $\mathrm{R} v$ Inspectorate of Pollution, ex parte Greenpeace Ltd (No 2) [1994] 4 All ER 329 and R v Secretary of State for Foreign Affairs, ex parte World Development Movement [1995] 1WLR 386.

48 For example, in the case of the Mid Staffordshire Inquiry, Cure the NHS. See < www.curethenhs.co.uk>. 
A minister's discretion over whether or not to convene an inquiry and, if so, the extent to which it will be held in public, is very broad. As seen above, the decision-making process is neither open nor transparent, which has in turn raised significant concern about the motivation behind such decisions, particularly where the actions of the minister's department, or the government itself, would be under scrutiny in any subsequent public inquiry. However, concern over ministerial discretion exercised when setting up a public inquiry goes further. As can be seen from the IICSA, even when a public inquiry is announced, those who had called for the public inquiry may then refuse to participate because of the basis upon which it has been convened ${ }^{49}$ and whether it is a statutory or non-statutory inquiry, which can have a fundamental influence on the nature of the inquiry and public perception of its independence and integrity.

\section{Statutory and non-statutory inquiries}

\section{STATUTORY INQUIRIES HAVE 'MORE TEETH'}

When announcing the establishment of the Independent Panel Inquiry into Child Sexual Abuse in 2014, the Home Secretary justified the decision to make it a non-statutory inquiry on the basis that it can begin its work sooner and, because the basis of its early work will be a review of documentary evidence rather than interviews with witnesses who might themselves still be subject to criminal investigations, it will be less likely to prejudice those investigations'. ${ }^{50}$ The statement added that the panel would have access to government papers and be free to call witnesses from organisations in the public and private sectors, and in wider civil society, and, should the inquiry panel chair deem it necessary, the government would convert it into a statutory public inquiry. ${ }^{51}$

Five months later, in a statement before the Home Affairs Committee, ${ }^{52}$ following widespread media criticism and representations from survivors and their lawyers to the effect that they would not participate unless the inquiry was a statutory inquiry, the Home Secretary announced that the inquiry should have the powers of a statutory inquiry. After further intense pressure, the Home Secretary subsequently announced that the original Independent Inquiry Panel would be disbanded and a new 2005 Act Inquiry, the IICSA, would be convened, because of the 'robustness in law' of a statutory inquiry and its power to compel witnesses to give evidence. ${ }^{53}$

In order to understand the strength of feeling on the part of the survivors, it is important to look at the two key differences between statutory and non-statutory inquiries. The first is that, unlike in the case of non-statutory inquiries, the 2005 Act confers on statutory inquiries the power to compel the giving of evidence, including compelling witnesses to attend to give oral evidence, produce documents and provide a written statement. ${ }^{54}$ The Act also permits the chair to take evidence on oath, ${ }^{55}$ ensuring that anyone who gives false evidence could face criminal sanctions. Sometimes, merely the

49 Another example being the family of Patrick Finucane, Northern Ireland solicitor, who initially opposed the establishment on an inquiry under the 2005 Act because of the powers given to ministers to impose restrictions on the disclosure and publication of evidence (see further discussion below).

50 HC Deb 7 July 2014, vol 584, col 25.

51 Position restated in HC Deb 3 November 2014, vol 587, col 543.

52 <http://data.parliament.uk/writtenevidence/committeeevidence.svc/evidencedocument/home-affairscommittee/the-work-of-the-home-secretary/oral/16895.html>

53 HC Deb 4 February 2015, vol 592, cols 276-77.

542005 Act, s 21.

55 Ibid s 17. 
existence of powers to compel the giving of evidence, without enforcement, is sufficient to make a difference to the effectiveness of an inquiry.

Counsel to the Robert Hamill Inquiry ${ }^{56}$ explained that, when the inquiry was set up, it did not have powers of compulsion over witnesses:

We were told unequivocally that the Protestant witnesses who were on the street and were vital to it would not give evidence. We were able to convert, thinking we needed to convert, to get powers under the 2005 Act, and as soon as we had the powers we had the witnesses ... As far as we are concerned, the real distinction between a non-statutory inquiry and a statutory inquiry is those teeth. ${ }^{57}$

The second key difference is that, under the 2005 Act, there is a presumption that the hearings will be held in public. Subject to restrictions imposed by the minister or chair, 58 the chair must take such steps as he or she considers reasonable to secure that members of the public (including reporters) are able:

(a) to attend the inquiry or to see and hear a simultaneous transmission of proceedings at the inquiry;

(b) to obtain or to view a record of evidence and documents given, produced or provided to the inquiry or inquiry panel. ${ }^{59}$

The intention is to provide transparency and openness to the proceedings whereby the public, by attendance, or by the press televising or reporting the proceedings, are free to draw their own informed conclusions. It also provides interested parties with an often much sought-after opportunity for their voices to be heard.

Despite clear advantages to convening a statutory inquiry and the fact that the 2005 Act is generally recognised to be 'good legislation', 60 when exercising their discretion, ministers have frequently chosen to set up alternative forms of non-statutory inquiry or investigation, such as a Parliamentary Inquiry, Counsel of Privy Councillors, Royal Commission or independent review with elements of a public hearing. These nonstatutory versions include high-profile inquiries such as the Chilcot Inquiry into the Iraq conflict, the Butler Inquiry into intelligence on weapons of mass destruction and the Bichard Inquiry into child protection procedures following the Soham murders. ${ }^{61}$

Serious questions have been raised about the motivation behind decisions not to convene a statutory inquiry and the effect on public perception and trust. Once again, there is neither a formal process nor criteria by which to determine if an inquiry is to be statutory or non-statutory and no openness or transparency to the decision-making process. ${ }^{62}$ There is a concern that ministers are apparently choosing to side-step the

56 Inquiry into the actions of the Royal Ulster Constabulary following the death of Robert Hamill.

57 Ashley Underwood, oral evidence taken before the HL Select Committee (20 November 2013) (n 20 ) Q250.

582005 Act 2005, s 19.

59 Ibid s 18.

60 See HL Select Committee (n 11) para 214. However, there have been notable critics, particularly when the Inquiries Bill was first presented, chiefly over ministerial powers and the use of restriction notices, including: the panel members of the Bloody Sunday Inquiry; Amnesty International; and in an all-party motion introduced before Dáil Éireann. See the discussion in Beer et al (n 14) paras 1.67-71. Concern since appears to have eased for some, as the extent to which those powers have been used in practice has not been as great as initially feared (see $\mathrm{n} 75$ below).

61 Inquiry into child protection procedures in Humberside Police and Cambridgeshire Constabulary following the murder of Jessica Chapman and Holly Wells.

62 It would appear that informal discussions take place at ministerial level and the Prime Minister has the final say: see Shailesh Vara MP, oral evidence taken before the HL Select Committee (11 December 2013) (n 20) Q327-28. 
legislation when it suits them because it is felt the 2005 Act somehow 'ties their hands, is too complicated, [or] is too public'. ${ }^{63}$ During the HL Select Committee, Baroness Buscombe posed the question:

Why should the public have any trust in a non-statutory inquiry when, the very people who were behind that legislation instantly chose to avoid it when, for example, setting up the Iraq inquiry? ${ }^{64}$. . . Can we not read from that, being cynical, that this means that some of the truth can be avoided where the inquiry is non-statutory? 65

There is no express presumption in favour of using the 2005 Act, in the Act itself or elsewhere. Convening non-statutory inquiries under the general ministerial prerogative is a well-established practice. In the pre-2005 Court of Appeal case of Crampton, ${ }^{66}$ Sir Thomas Bingham MR stated that, simply because a statute gives a minister power to establish an inquiry, it does not mean the minister lacks authority to establish an inquiry of any other kind, nor that the minister must establish all inquiries under the statute that provides compulsory powers. However, in the House of Lords debate on the 2014 Select Committee Report, Lord Trimble referred to one of the main intentions behind the 2005 Act and the explanatory notes to the 2005 Bill, which was 'to consolidate numerous pieces of subject-specific legislation' and 'to provide a comprehensive statutory framework for inquiries set by Ministers to look into matters of public concern'67 stating that:

That language points to the Act being used for inquiries generally. It does not say that the Act is optional . . That would be a rather novel proposition for legislation. I know that the practice has developed of non-statutory inquiries and it is perhaps late in the day to challenge that now. However, I suggest that it is not really within the original intention of the Act, which is why we made the recommendations we did . . .68

The Select Committee recommended that:

... inquiries into issues of public concern should normally be held under the Act.

This is essential where Article 2 of the ECHR is engaged. ${ }^{69}$ No inquiry should

63 Ibid Lord Richard (11 December 2013) Q323.

64 The Chilcot Inquiry.

65 See question of Baroness Buscombe, oral evidence taken before the HL Select Committee (10 July 2013) (n 20) Q36.

66 Crampton (n 24).

67 Explanatory Notes to the Inquiries HL Bill (2004-2005) para 3. There are only a very few examples of alternate legislation continuing to apply, such as the Financial Services Act 2012 or the Merchant Shipping Act 1995.

68 HL Deb 19 March 2015, vol 760, col 1143. See also R v Secretary of State for the Home Department, ex parte Fire Brigades Union and Others [1995] 2 AC 513 where the House of Lords ruled that the Home Secretary had acted unlawfully in failing to implement, by statutory instrument, a statutory scheme for criminal injuries compensation under the Criminal Justice Act 1998, choosing instead to amend an existing non-statutory scheme under the Royal Prerogative.

69 Articles 2 and 3 ECHR impose on governments an obligation to conduct an effective official investigation into any death resulting from the use of force or resulting from the state's failure to protect the right to life (see, for example, the ECHR determination in Osman v UK (1998) 29 EHRR 245; McCann v UK (1995) 21 EHRR 97), including the need for there to be a 'sufficient element of public scrutiny' (see Lord Bingham's summary of the Article 2 requirements in $R$ (Amin) $v$ Secretary of State for the Home Department [2003] UKHL 51). It is only inquiries with statutory powers to compel the production of documents and the attendance of witnesses to give evidence on oath that will be compliant with Article 2. Also, the lack of rules governing public and private hearings are more likely to result in non-statutory inquiries being non-compliant with Article 2 than statutory inquiries. See HL Select Committee (n 11) paras 69-76. 
be set up without the power to compel the attendance of witnesses unless ministers are confident that all potential witnesses will attend.

It recommended retaining the possibility of inquiries being held otherwise than under the Act where, for example, security issues are involved, or other sensitive issues which require evidence to be heard in secret, adding 'Ministers should give reasons for any decision to hold an inquiry otherwise than under the Act. ${ }^{70}$

This was rejected by the government, asserting that the 2005 Act represents an important starting point and that 'Ministers should not feel constrained from considering other options which may be better suited to the circumstances', interpreting s $1(1)^{71}$ as being merely permissive, providing flexibility as to whether to use the Act or not, noting that s 15 allows for conversion into a 2005 Act inquiry if organisations or individuals refuse to co-operate with a non-statutory inquiry. ${ }^{72}$

\section{CHOOSING A NON-STATUTORY INQUIRY}

Whilst taking great issue with the government's rejection of the recommendation that public inquiries should normally be held under the 2005 Act, for reasons of public perception and trust and discussed in greater detail below, it is accepted that there will be occasions where convening a non-statutory inquiry will be appropriate. Examples might include where there is a need for evidence to be heard in secret for the protection of matters of national importance and national security or where the release of material might jeopardise economic measures concerning Britain's economy. ${ }^{73}$ It may also be concluded, for example, that powers of compulsion over witnesses are not appropriate because evidence is being sought from citizens of foreign jurisdictions. ${ }^{74}$ In such cases, there is a balance to be found between the need to maximise the public nature of an inquiry and the importance of enabling an effective investigation to take place. An inquiry with severe restrictions to public access might, on occasion, be better than no inquiry at all. ${ }^{75}$

Practical arguments have also been put forward in favour of non-statutory inquiries. Sir John Chilcot, chair of the Chilcot Inquiry, felt that 'the powers of compulsion contribute to an overly formal or court-like adversarial process' in what is an inquisitorial procedure. ${ }^{76} \mathrm{~A}$ number of witnesses appearing before the HL Select Committee thought that the taking of evidence on oath would not make a practical difference, largely because, with the mass of documents and other evidence before the inquiry, anyone lying risked being caught out and anyone minded to lie would do so on oath or otherwise. ${ }^{77}$

70 HL Select Committee (n 11) paras 81-82.

71 'A Minister may cause an inquiry to be held under this Act.'

72 Ministry of Justice (n 12) para 31.

73 See Shailesh Vara MP, oral evidence taken before the HL Select Committee (11 December 2013) (n 20 ) Q321.

74 See, for example, ibid, Peter Riddell (17 July 2013) Q59.

75 An alternative argument: the family of Patrick Finucane, a Northern Ireland solicitor, initially opposed the establishment of an inquiry under the 2005 Act into his murder by paramilitaries and collusion by the state because of the power conferred on the minister by the Act to impose restrictions on the disclosure and publication of evidence. The family subsequently changed its position, having seen the 2005 Act in practice and having received undertakings regarding the use of restriction notices. (However, the government ultimately decided to hold an independent review rather than the public inquiry that had been promised to the family. The family brought judicial review proceedings Re (Finucane) v Secretary of State for Northern Ireland [2015] NIQB 57) and an appeal against partial dismissal of the application for judicial review has been listed before the Court of Appeal.

76 HL Select Committee (n 11) para 68.

77 See Public Administration Select Committee (n 33) para 113 and, for example, Professor Tomkins and Sir Stephen Sedley, oral evidence taken before the HL Select Committee (10 July 2013) (n 20) Q36. 
However, irrespective of the extent to which it is thought that statutory powers of compulsion over witnesses would make a practical difference, thought must be given to the fact that choosing to convene a non-statutory inquiry can, and does, give rise to major issues over public perception and trust. A 2010 Cabinet Secretary advice note stated:

Non-statutory inquiries (e.g. Chilcot) are normally used where the actions in question are mainly those of public officials, who can be expected (or to an extent required by government) to cooperate without the need for the inquiry to have powers of compulsion. If such cooperation is not forthcoming a nonstatutory inquiry can be turned into a statutory one, with the relevant powers. ${ }^{78}$

A major role of public inquiries is to hold the executive to account. I would argue strongly therefore that, where the actions in question are mainly those of public officials, for example, in a case such as the IICSA, dealing with allegations of an establishment coverup, ${ }^{79}$ it is even more important to ensure public perceptions of integrity and to ensure that, from the outset, there is a presumption that hearings will be held in public and that the inquiry is given powers of compulsion over witnesses and the power to take evidence on oath.

\section{Public INFLUenCE}

The background to the establishment of the IICSA shows that pressure from survivors and their families, pressure groups, the public and media can result in a decision to convert, or disband, a non-statutory inquiry in favour of convening a statutory inquiry. It remains to be seen whether this is the start of public pressure increasing the proportion of statutory rather than non-statutory inquiries that are convened.

Relying on this form of public pressure as a process of accountability brings with it its own concerns. The failure to get the model right from the outset, and ministers being seen to backtrack on previous decisions, risks damaging confidence in the public inquiry process itself. A further concern is the way in which this can lead to inconsistencies between inquiries. In the case of the IICSA, the survivors, their families and the pressure groups were well informed about the significance of the distinction between the two types of inquiries. Most members of the wider general public are unlikely to know if an inquiry is statutory or non-statutory, nor appreciate the significance. Many might simply assume that a public inquiry, set up to investigate such serious issues, would have the power to enable it to take evidence on oath and require documents to be produced, in a way they are familiar with in the court system. Limited public understanding of the implications of the decision made reduces the potential for public scrutiny and the potential for public pressure to be brought to bear.

The power of a minister to decide whether or not a public inquiry will be a statutory or non-statutory inquiry is hugely significant because of the profound effect that decision can have on the powers, effectiveness and degree of openness of the subsequent inquiry, the role of which is to hold those in authority to account. The fact that unease is expressed over ministers appearing to deliberately side-step the use of the 2005 Act when it suits is a major cause for concern. In the case of the IICSA, public pressure was sufficient to force a change but, in that case, the calls went further. A further, highly contentious issue was the identity of the chair to the inquiry.

78 See Cabinet Secretary Advice Note (n 16).

79 See Peter Wanless and Richard Whittam, 'An Independent Review of Two Home Office Commissioned Independent Reviews Looking at Information Held in Connection with Child Abuse from 1979-1999' (11 November 2014) <www.gov.uk/government/uploads/system/uploads/attachment_data/file/372915/ Wanless-Whittam_Review_Report.pdf $>$. 


\section{The chair}

\section{SIGNIFICANCE}

The choice of chair is critical to the success of a public inquiry. If the public is to have confidence in the inquiry process and its recommendations it must have confidence in the chair. The public identifies with the chair; often, for example, with the Leveson and Chilcot Inquiries, an inquiry is identified by, and inextricably linked with, the identity of its chair.

The majority of inquiries are chaired by a judge, ${ }^{80}$ retired judge, or senior member of the legal profession, ${ }^{81}$ chosen for their experience and expertise in assessing and handling large volumes of evidence, their publicly recognised independence and their proven integrity and authority. Others are chaired by senior civil servants, ${ }^{82}$ or others outside of the legal professions, ${ }^{83}$ known for their standing and expertise in the subject matter of the inquiry, or in the operation of public sector bodies, or where the highly politically sensitive nature of the inquiry means it is not appropriate for a judge to be involved. ${ }^{84}$ The inquiry may be undertaken by the chair alone, or with one or more other members forming an inquiry panel. In addition to sharing the workload, panel members may bring a diversity of professional backgrounds, expertise, knowledge and perspective. The existence of a panel can also enhance public confidence in the fairness of the process and add credence to the inquiry's conclusions. ${ }^{85}$

\section{TIMING}

Despite the choice of chair being critical to the success of the inquiry, the appointment process and announcement is often carried out in alarming haste. Under s 6 of the 2005 Act, when convening a 2005 Act public inquiry, the minister must make a statement to Parliament to that effect, 'as soon as is reasonably practicable'. ${ }^{86}$ That statement must also specify who has been appointed as chair and whether the minister has, or proposes to appoint, any other members to the panel. ${ }^{87}$ Mounting public pressure to announce the establishment of a public inquiry, and the fact that both statements must be made at the same time, means the selection process may take place over a very short period of time with very little time for deliberations and, at times, an astonishingly short amount of time for discussions with the proposed chair in advance of the announcement. Sir Robert Francis, the chair of the Mid Staffordshire Inquiry, in his evidence to the HL Select Committee, stated that he was phoned up without warning and asked to decide within an hour whether to accept the appointment 'because the Minister was in a hurry to make an

80 Which requires consultation with the Lord Chief Justice, s 10(1) 2005 Act, which is due to be changed to requiring consent rather than consultation. See Ministry of Justice (n 12) para 40.

81 Such as the Bloody Sunday, Hamill, Al Sweady, Azelle Rodney and Leveson Inquiries.

82 For example, the Butler and Chilcot Inquiries.

83 For example, the Foot and Mouth and Climbié Inquiries.

84 Lord Woolf, cited in Public Administration Select Committee (n 33) para 187.

85 Sarah Garner, Peter Jones and Isabelle Mitchell, 'Public Inquiries: Appointments' Insight (18 June 2013) available via Westlaw.

862005 Act, s 6(1).

87 Ibid s 6(2). 
announcement'. ${ }^{88}$ Sir John Chilcot had 10 minutes in which to accept the invitation to chair the Inquiry into the Iraq conflict. ${ }^{89}$

The 2014 Select Committee Report stated:

We are not saying that ministerial haste has ever resulted in the appointment of a chairman whose appointment might subsequently have been regretted, but there is much to be said for a process which is less hurried and more transparent ... We believe the fact of the inquiry and the name of the chairman should not necessarily be the subject of the same statement, and we recommend that section 6(2) should be amended accordingly. ${ }^{90}$

This recommendation was accepted by the government, ${ }^{91}$ but the relevant legislation has yet to be amended. Once in force, it will allow the minister greater time in which to consider the appointment and hear representations from victims, survivors and their families and other interested parties. The extent to which this will transpire in practice remains to be seen.

\section{INDEPENDENCE}

The chair must be impartial ${ }^{92}$ and that impartiality must be beyond doubt in order to command public trust in the chair and the inquiry itself. A difficult balance needs to be struck between identifying an individual with sufficient knowledge, expertise and interest in the issues and them being so close to the subject matter of the inquiry as to give rise to a conflict of interest. ${ }^{93}$ Once again, neither the decision-making process nor the criteria applied in any given case are in the public domain, limiting the scope for public scrutiny. Draft Cabinet Office Guidance, ${ }^{94}$ which is non-binding, states only that, when making an appointment:

... the Minister may seek advice from professional, regulatory or other bodies in the appropriate field ... the department should not approach any individual until the Minister has been consulted ... The Lord Chancellor and Secretary of State should be consulted where there is a proposal to appoint a judge or legal officer. ${ }^{95}$

Advice is likely to be sought from people who have handled inquiries and dealt with the proposed chair in the past. In politically contentious matters, the Prime Minister would be consulted. ${ }^{96}$

This is in sharp contrast, however, to the appointment of judges where the Judicial Appointments Commission (JAC), an independent public body, is responsible for selecting candidates to recommend for judicial appointment. The JAC includes lay members, who provide an independent voice and ensure a public input into the appointment, distancing the process from political influence. The Lord Chancellor's role

88 Robert Francis QC, oral evidence taken before the HL Select Committee (30 October 2013) (n 20 ) Q205.

89 Oral evidence taken before the Foreign Affairs Select Committee (4 February 2015) <http://data.parliament.uk/writtenevidence/committeeevidence.svc/evidencedocument/foreign-affairscommittee/progress-of-the-iraq-inquiry/oral/17950.html>.

90 HL Select Committee (n 11) para 114.

91 Ministry of Justice (n 12) para 39.

922005 Act, s 9.

93 See Garner et al (n 85).

94 Cabinet Office, Inquiries Guidance: Guidance for Inquiry Chairs, Secretaries and Sponsor Departments <www.parliament.uk/documents/lords-committees/Inquiries-Act-2005/caboffguide.pdf>.

95 With reference to the Cabinet Office, Ministerial Code, May 2010, para 4.11.

96 Shailesh Vara MP, oral evidence taken before the HL Select Committee (11 December 2013) (n 20 ) Q332. 
in the appointment of individual members of the judiciary is deliberately limited to avoid the risk of 'politicising the appointments process' and 'undermining the independence of the judiciary'. ${ }^{97}$ As a result, particularly where the chair is not a member of the judiciary, the lack of independence of the current process, coupled with its lack of transparency, makes it vulnerable to allegations of politically motivated appointments and raises concern that those appointed lack sufficient independence from the executive and political establishment.

The lack of openness to the decision-making process may also give rise to wider concerns over independence. Shortly after the appointment of Lord Leveson, ${ }^{98}$ a senior member of the judiciary, to the position of chair to the Inquiry into the Culture, Practice and Ethics of the Press, reports emerged of Lord Leveson having recently attended two parties at the home of Rupert Murdoch's son-in-law. Questions were raised about his ability to be seen to be independent. Chris Bryant, the Labour MP who had been campaigning on phone-hacking, said: 'If this had been known from the start it might be fine - as with every step, transparency has come by dragging it out of them. ${ }^{99}$

Links with the establishment were a major cause for concern when the Independent Panel Inquiry into Child Sexual Abuse was convened in 2014. The Home Secretary announced that the panel chair would be Baroness Butler-Sloss, ${ }^{100}$ the first female Lord Justice of Appeal and, until 2004, the highest-ranking female judge in the UK, and an expert in the field of child protection and the chair of the Cleveland Child Abuse Inquiry. From the time of the announcement, however, many expressed concerns over Baroness Butler-Sloss's links to the establishment, as the sister of the former Lord Chancellor Michael Havers, Attorney General in the 1980s, and over his role in previous investigations. Whilst not questioning Baroness Butler-Sloss's integrity, there was concern that she would be seen as part of the establishment, which would undermine public confidence. Following intense pressure from victims groups, MPs and the media, ${ }^{101}$ within a week Baroness Butler-Sloss had stepped down.

Two months later it was announced that Fiona Woolf, a solicitor who had held a number of senior positions including President of the Law Society and Lord Mayor of London, had been appointed as the new chair. ${ }^{102}$ Fiona Woolf soon faced calls to resign, from survivors groups and MPs, ${ }^{103}$ and there was widespread media coverage over personal links with the former Home Secretary, Lord Brittan, who was Home Secretary in the 1980s and who was likely to be called to give evidence over his handling of allegations of abuse during his time in office. ${ }^{104}$

97 See Select Committee on the Constitution, Judicial Appointments (HL 2010-2012, 272) paras 26 and 139.

98 Lord Justice of Appeal.

99 Christopher Hope, 'Phone Hacking Inquiry Judge Attended Parties at Home of Rupert Murdoch's Son-inlaw' The Telegraph (London, 22 July 2011) <www.telegraph.co.uk/news/uknews/phone-hacking/8656131/ Phone-hacking-inquiry-judge-attended-parties-at-home-of-Rupert-Murdochs-son-in-law.html>.

100 HC Deb 9 July 2014, vol 584, col 20WS.

101 Such as Mary Dejevsky, 'Elizabeth Butler-Sloss is Too Close to the Establishment to Lead this Abuse Inquiry' The Guardian (London, 10 July 2014) <www.theguardian.com/commentisfree/2014/jul/10/elizabeth-butlersloss-establishment-child-abuse-inquiry $>$.

102 HC Deb 5 Sep 2014, vol 585, col 28WS.

103 Such as Matthew Weaver and Fiona Mason, 'Child Abuse Inquiry: Woolf Pressed to Quit over "Dinner Parties with Brittan"” The Guardian (London, 22 October 2014) < www.theguardian.com/society/2014/oct/22/childabuse-inquiry-fiona-woolf-dinner-parties-lord-brittan $>$.

104 Lord Brittan died on 21 January 2015, prior to being called to give evidence before the inquiry. 
The government stood by the appointment. However, after mounting pressure, and survivors' pledges to boycott an inquiry with her in the chair, ${ }^{105}$ Fiona Woolf resigned, recognising she did not command the survivors' confidence. It was subsequently announced $^{106}$ that the original panel would be disbanded and Justice Lowell Goddard, a New Zealand High Court Judge with no ties to the UK establishment nor persons likely to be investigated, would chair a new 2005 Act inquiry, the IICSA, assisted by panel members. ${ }^{107}$ As the Home Secretary stated when first announcing the inquiry, "With allegations as serious as these, the public needs to have complete confidence in the integrity of the investigation's findings . . ', 108

It is clear that public pressure can bring sufficient weight to bear to influence the appointment and the government must listen to the concerns of the public. However, as argued above, public pressure from individuals and pressure groups via the media, social media and the lobbying of MPs is an inconsistent form of accountability. Further, there have been words of caution over the nature of public consultation. Sharon Evans, one of the original panel members of the Independent Panel Inquiry into Child Sexual Abuse, warned against listening to the vocal minority 'engaging in personal attacks against panel members' instead of the majority of abuse survivors. ${ }^{109}$ Baroness Butler-Sloss cautioned against giving victims too much influence over who chairs an inquiry and facing the risk of having a chair without the necessary experience for the role. ${ }^{110}$ The chair ${ }^{111}$ appointed must be seen to be impartial and independent in all respects: independent from the government and the executive, but also independent from survivors, their families, NGOs, pressure groups and the media.

\section{Terms of reference}

\section{CONSULTATION}

The final power exercised by a minister when convening a public inquiry is the power to set the terms of reference. The terms of reference are a crucial factor in determining an inquiry's ambit, length, complexity, cost and ultimately its success. An inquiry may only investigate those matters that are covered by its terms of reference. ${ }^{112}$ If the terms of reference are too wide, it may result in unnecessary cost and delay, and may introduce extraneous questions which merely confuse the essential issues. ${ }^{113}$ If the terms of reference are too narrow, it may appear that the government is attempting to deflect criticism or avoid difficult political issues by restricting the scope of the inquiry.

105 David Barrett, 'Abuse Victims Pledge to Boycott Fiona Woolf inquiry' The Telegraph (London, 31 October 2014) <www.telegraph.co.uk/news/uknews/law-and-order/11200795/Abuse-victims-pledge-to-boycottFiona-Woolf-inquiry.html>.

106 HC Deb 12 March 2015, vol 594, col 40WS.

107 Professor Malcolm Evans OBE; Ivor Frank; Professor Alexis Jay OBE; and Drusilla Sharpling CBE. The new panel, unlike its predecessor, does not include victims of child sexual abuse, but is supported by a consultative panel including victims and survivors, thus strengthening its perceived independence.

108 HC Deb 7 July 2014, vol 755, col 54.

109 Mark Watts, 'Theresa May to Scrap Panel for Inquiry into Child Sex Abuse' ExaroNews (London, 20 December 2014) <www.exaronews.com/articles/5438/theresa-may-to-scrap-panel-for-inquiry-into-child-sex-abuse> .

110 'Butler-Sloss Cautions over Victims' Role in Abuse Inquiry' BBC News (London, 31 December 2014) <www.bbc.co.uk/news/uk-30640879>.

111 And panel members.

1122005 Act, s 5(5).

113 See Public Administration Select Committee (n 33) para 74. 
The minister convening an inquiry is responsible for setting the terms of reference ${ }^{114}$ and may at any time amend them if he or she considers that the public interest so requires. ${ }^{115}$ Whilst Parliament must be informed of the terms of reference of a statutory inquiry, ${ }^{116}$ it has little involvement in determining the terms of reference of either statutory or non-statutory inquiries.

In contrast to the previous decisions made when convening a public inquiry, when setting the terms of reference of a statutory inquiry there is a legal requirement for the minister to consult. Section 5(4) of the 2005 Act provides: 'Before setting out or amending the terms of reference of a statutory inquiry, the minister must consult the person he proposes to appoint, or has appointed, as chairman.' However, in practice, the extent of the consultation is often extremely limited. There is often strong public and political pressure to announce an inquiry and its terms of reference very quickly. Consultation frequently takes place before the chair has had chance to undertake more than a very cursory consideration of very limited material and before the chair is well placed to provide meaningful input. ${ }^{117}$ In evidence to the HL Select Committee, Sir Robert Francis spoke of the 'panic' when a public inquiry is announced with terms of reference stating: 'A chairman is found at an hour's or even less notice and given some terms of reference, which of course he is "consulted on" at a point where he has no more information than he has read in the newspapers about the subject.'118 The minister may subsequently rely on the power to amend terms of reference, but that brings with it the risk of undermining work that has already been undertaken or creating a lack of clarity that exposes the inquiry to judicial review challenges.

As with the announcement of the chair, for statutory inquiries, the terms of reference have to be announced in the same statement to Parliament as the announcement of the inquiry itself. ${ }^{119}$ The 2014 Select Committee Report recommended that a short 'coolingoff' period be allowed after an announcement of an inquiry and draft terms of reference, while the chair familiarises him or herself with the material and consultation takes place, with the final terms of reference being the subject of a separate statement. ${ }^{120}$ In its response, the government rejected this suggestion, stating 'terms of reference and any amendments to them, are invariably discussed and agreed with the chair' adding 'it is neither practical nor sensible for there to be two sets of terms of reference in the public domain'.121

Whilst it may be possible in some cases to clearly define the terms of an inquiry from the outset, there will be many instances where that is not the case. It is argued that the government's response fails to address the reality of the situation, which is that, due to time pressure, consultation that currently takes place at this stage is often merely perfunctory and discussion over the final terms of reference continue once the chair has

1142005 Act, s 5(1)(b) for inquiries convened under the 2005 Act.

115 Ibid s 5(3) for inquiries convened under the 2005 Act.

116 Ibid s 6(1).

117 Jason Beer QC, oral evidence before the HL Select Committee (16 October 2013) (n 20) Q121; Robert Francis QC, written evidence para 42; and Julie Bailey oral evidence (23 October 2013) Q160.

118 Ibid Robert Francis QC, oral evidence (30 October 2013) Q215.

119 Inquiries Act 2005, s 6(2).

120 Also recommending that the consent of the chair be required to set or amend terms of reference, rather than the current requirement to consult: HL Committee (n 11) paras 144-46.

121 Ministry of Justice (n 12) paras 52-53. 
had the opportunity to familiarise him or herself with the material. ${ }^{122}$ Relying on powers to amend risks undermining public confidence in the process and exposing it to legal challenge. There is a strong argument that the process would be better served by regularising the position by a change to the legislation to allow for initial draft, or indicative, terms of reference to be announced, with final terms of reference being the subject of a separate statement following a short period of meaningful consultation.

\section{INFLUENCE}

In addition to consultation with the chair, witnesses before the HL Select Committee also called for the minister to be required to have regard to, though not be bound by, consultation with core participants ${ }^{123}$ and the wider public, who may have valuable input on the formulation of the terms of reference. ${ }^{124}$ Currently, whether statutory or nonstatutory, practice can differ greatly between inquiries. The Foot and Mouth and Detainee Inquiries, both non-statutory inquiries, did have a period of consultation for three months before the Inquiry started, during which there were discussions between the chair and government representatives, as well as informal consultation with relevant stakeholders. ${ }^{125}$ The Chilcot Inquiry, also non-statutory, had no consultation at all. ${ }^{126}$ The core participants to the $\mathrm{Al}$ Sweady Inquiry, a statutory inquiry, were given an opportunity to feed into the terms of reference and the chair invited comments on the terms of reference at the outset of the proceedings. ${ }^{127}$ In contrast, there was no consultation exercise on the Mid Staffordshire Inquiry, a statutory inquiry, because of the time pressure under which the inquiry was operating. ${ }^{128}$

Whilst not going so far as including 'the wider public', the 2014 Select Committee Report recommended that interested parties, particularly victims and victims' families, should be given an opportunity to make representations about the final terms of reference, 'which may have the additional benefit of avoiding judicial review of the terms of reference, as happened with the Robert Hamill Inquiry'. ${ }^{29}$ The government accepted the recommendation in part, with the caveat that 'this proposal would not be helpful in cases where the Government wished to respond swiftly to an issue or issues of public concern and it would be potentially problematic in cases where there are multiple victims', ${ }^{130}$ leaving the position open to varied interpretation. As a result, the potential for terms of reference to be decided in undue haste, without the benefit of wider consultation, remains. A change in legislation allowing final terms of reference to be announced in a separate statement to the announcement of the inquiry, after a period of

122 This response also raises issues of timing. As discussed above, the government has accepted the recommendation that the announcement of the identity of the chair may form the subject of a later statement. As a result there may be no chair available for consultation over the terms of reference at the time the inquiry is announced.

123 A few interested parties with a particularly close connection with the work of the inquiry may be formally recognised by the inquiry and designated a privileged status, known as 'core participant status', which is the primary means of direct access to the inquiry process. The term 'core participants' is used in statutory inquiries convened under the Inquiries Act 2005. In non-statutory inquiries the terms 'interested parties' or 'full participants' may be used.

124 See, for example, Eversheds written evidence to the HL Select Committee (n 20) para 12; and Robert Francis QC oral evidence (30 October 2013) Q215.

125 Ibid Alun Evans, oral evidence (16 October 2013) Q131.

126 Oral evidence taken before the Foreign Affairs Select Committee (n 89) Q3.

127 Susan Bryant, oral evidence taken before the HL Select Committee (6 November 2013 ) (n 20) Q238.

128 Robert Francis oral evidence taken before the HL Select Committee (30 October 2013) (n 20) Q215.

129 HL Select Committee (n 11) paras 150-51.

130 Ministry of Justice (n 12) para 55. 
meaningful consultation with the chair, would also allow time for consultation with interested parties and, if appropriate, the wider public.

Consultation and engagement with core participants and the wider public may also assist with managing expectations. In evidence to the HL Select Committee, Peter Riddell, a panel member of the Detainee Inquiry, ${ }^{131}$ spoke of the difficulties and frustrations over the inquiry's terms of reference. During that inquiry, there was a clash of expectations between the panel's focus on the awareness of the British government and intelligence agencies of alleged mistreatment of British detainees and the expectations of the detainees and NGOs that there would be inquiries into allegations of torture. ${ }^{132}$ This led ultimately to a boycott by the detainees, their lawyers and NGOs. During the same evidence session, Karl Mackie on behalf of CEDR ${ }^{133}$ suggested:

. . . a one-month period of consultation, particularly with key potential stakeholders in the inquiry subject matter, to consider how to draft terms of reference that match the needs of the parties and create legitimate expectations of what the inquiry process could deliver rather than have a problem of expectations at the end of the process ... ${ }^{134}$

The IICSA illustrates how public pressure outside a formal consultation process may, on occasions, be sufficient to influence or force the amendment of an inquiry's terms of reference. The terms of reference for the original non-statutory Independent Panel Inquiry into Child Sex Abuse set out the scope of the inquiry, including the statement that the inquiry panel would 'cover England and Wales' and 'consider these matters from the 1970 s to the present'. ${ }^{135}$ When, in 2015, in response to sustained public pressure and the resignation of two chairs to the inquiry, the panel was disbanded and a new statutory inquiry convened, the Home Secretary also reviewed the terms of reference in light of feedback from survivors. This resulted in a widening of the scope of the inquiry, including the removal of any cut-off date for the work of the inquiry and liaison to take place between the inquiry and its counterparts elsewhere in the UK. ${ }^{136}$ However, as seen above, such change is dependent on well-mobilised groups building a momentum of publicity and support, sufficient to trigger engagement of the minister, and is no substitute for a formal process of consultation.

Whether through formal or informal processes, public consultation must be carefully managed. Not all public concerns can or will be addressed in the final terms of reference, which may result in the public feeling ignored. Clear communication of what is and is not to be considered by the inquiry is essential, as is the extent to which an inquiry is or is not required to make findings of responsibility and accountability. ${ }^{137}$

$131<$ www.detaineeinquiry.org.uk>

132 Peter Riddell, oral evidence taken before the HL Select Committee (17 July 2013) (n 20) Q59.

133 Centre for Effective Dispute Resolution.

134 Dr Karl Mackie, oral evidence taken before the HL Select Committee (17 July 2013) (n 20) Q59.

135 <http://data.parliament.uk/DepositedPapers/Files/DEP2014-1359/Terms_of_reference_CSA_ Inquiry.pdf $>$

136 HC Deb 12 March 2015, vol 594, col 41WS. As child protection is a devolved matter, other jurisdictions in the UK will look at the issues within their own geographical remit. However, joint protocols will be set up with counterpart inquiries in Scotland, Northern Ireland and in Jersey to ensure that information can be shared and lines of investigation can be followed across geographical boundaries.

137 See CEDR, 'Inquiries into Inquiries Outcome of Symposium and Proposed Next Steps' (available from CEDR) 24 April 2013. 
The Chilcot Inquiry ${ }^{138}$ has been the subject of much criticism, including for its length and the delay in publishing its report. One of the difficulties facing the inquiry was that its terms of reference are so broad. The inquiry was set up to consider Britain's involvement in the Iraq conflict between mid-2001 and July 2009, from the run-up to the conflict and the subsequent military action to its aftermath. When speaking to the $\mathrm{BBC}$, Lord Butler ${ }^{139}$ stated that governments, when setting up inquiries of this sort, 'try to satisfy everybody ... They do not want to be seen to be restricting anything, which can, or does, lead to great problems.' He concluded that, when pressing for a public inquiry with a wide remit, people need to be mindful of unforeseen consequences. There is the potential for complainants to press for an inquiry to be so far-reaching it may not be manageable and they may be frustrated in the results sought. ${ }^{140}$ In the case of the IICSA, the significant widening of the terms of reference in light of feedback from the survivors, whilst welcomed by those pressing for change, will also result in the survivors, who in many cases have already waited decades to be heard, facing a substantially longer and much more drawn-out process.

\section{Conclusion}

It is essential that the public has confidence and trust in the independence and integrity of an inquiry if it is to command confidence in its process and ultimately its findings. The minister is afforded considerable discretion over whether or not to convene a public inquiry, the extent to which any inquiry will be heard in public, its powers, the identity of its chair and the scope of its terms of reference. The way in which that discretion is exercised has a significant bearing on the nature and public perception of any subsequent inquiry.

Concerns are frequently raised about the motivation behind the exercise of the ministerial discretion. One of the key roles of a public inquiry is to hold those in authority to account and concern over conflicts of interest will inevitably arise where the minister exercising that discretion is a member of the establishment and is often the minister of the department, or a member of the government, that is itself under scrutiny. Irrespective of the extent to which concerns of this nature are justified, they undermine public confidence in the public inquiry process.

There have long been complaints over the lack of openness and transparency to the decision-making process, which exacerbates those concerns and reduces scope for public accountability and scrutiny. There is a lack of any formal structure for interested parties and the wider public to make representations to ministers and there are practical limitations to judicial review as a safeguard. The IICSA illustrates that public pressure can be sufficient to force a minister to revisit those decisions, but reliance on public and media pressure, in the absence of any formal process for representations or consultation, can give rise to inconsistent approaches between inquiries and to public uncertainty.

Whilst the Government Response to the 2014 Select Committee Report accepted some recommended changes to the decision-making process, to make it more transparent and open to public engagement, many recommendations were rejected. It is argued, an opportunity to improve public confidence and trust in the public inquiry process was missed. Publishing broad criteria or guidance by which to justify a decision whether or not to convene an inquiry, and the extent to which an inquiry will be heard in public, less haste and greater transparency to the appointment process for the chair, a presumption

138 Iran Inquiry

139 Chair of the Review of Intelligence on Weapons of Mass Destruction.

140 Lord Butler, 'The World at One' (BBC Radio 4, 23 January 2015) <www.bbc.co.uk/programmes/p02hhydk>. 
that public inquiries would normally be held under the 2005 Act and greater engagement and consultation with interested parties and the public over the terms of reference of a public inquiry would increase scope for greater public scrutiny and accountability and would go a long way to address many of the concerns expressed. In a 2013 letter from the Home Secretary to the coroner of the Litvinenko Inquest, one of the reasons given for initially refusing to convene a public inquiry into the events surrounding the death of Litvinenko, and possible Russian state involvement, was that:

An inquest managed and run by an independent coroner is more readily explainable to some of our foreign partners, and the integrity of the process more readily grasped, than an inquiry, established by the Government, under a Chairman appointed by the Government which has the power to see Government material, potentially relevant to their interests, in secret. ${ }^{141}$

It is not, however, only 'foreign partners' who need to understand the public inquiry process and be convinced of its integrity; this applies equally to the UK public as a whole.

141 Letter from The Rt Hon Theresa May to Sir Robert Owen (17 July 2013) <www.litvinenkoinquiry.org/wpcontent/uploads/2013/07/130717-HS-to-Coroner-redux.pdf>. 
